\title{
80 lat minęło ... XIV Kongres Międzynarodowej Unii Geograficznej w Warszawie, 23-31.08.1934
}

\author{
ANTONI JACKOWSKI, ELŻBIETA BILSKA-WODECKA, IZABELA SOŁJAN \\ Instytut Geografii i Gospodarki Przestrzennej, Uniwersytet Jagielloński \\ 30-387 Kraków, ul. Gronostajowa 7 \\ a.jackowski@geo.uj.pl.edu, e.bilska@geo.uj.edu.pl, i.soljan@geo.uj.edu.pl
}

Zarys treści. Decyzja o przyjęciu zaproszenia rządu polskiego do organizacji w 1934 r. XIV Kongresu Międzynarodowej Unii Geograficznej w Warszawie zapadła podczas Kongresu MUG w Paryżu w 1931 roku. Kongres odbył się w dniach 21-31 sierpnia 1934 r. i był pierwszym, jaki Unia zorganizowała w kraju słowiańskim.

W Kongresie uczestniczyły 693 osoby z 44 krajów. Z Polski wzięło udział około 360 osób. Zorganizowano 12 wycieczek o charakterze regionalnym i problemowym. Imprezie towarzyszyły wystawy kartograficzne. W latach 1935-1938 opublikowano 4 tomy Comptes Rendus du Congrès International de Géographie, zawierające referaty prezentowane podczas Kongresu.

Słowa kluczowe: historia geografii, Polska, międzynarodowy kongres geograficzny.

Organizowana w Krakowie w dniach 18-22 sierpnia 2014 r. Konferencja Regionalna Międzynarodowej Unii Geograficznej (MUG) odbywa się dokładnie w 80. rocznicę XIV Kongresu MUG, który zwołano do Warszawy w dniach 23-31 sierpnia $1934 \mathrm{r}$. W międzyczasie Polacy nie organizowali tak wielkiej i ważnej imprezy geograficznej o zasięgu światowym. Dlatego proponujemy, aby choć chwilę poświęcić tamtemu historycznemu spotkaniu, które miało istotne znaczenie dla rozwoju polskiej geografii.

Choć Międzynarodowa Unia Geograficzna powstała dopiero w 1922 r., geografowie spotykali się na światowych imprezach naukowych znacznie wcześniej. Pierwsze takie zgromadzenie miało miejsce w 1871 r. w Antwerpii. Do wybuchu I wojny światowej odbyło się łącznie dziesięć spotkań, ostatnie w 1913 r. w Rzymie. Organizowano je w takich krajach, jak Belgia, Francja (dwukrotnie), Włochy (dwukrotnie), Szwajcaria (dwukrotnie), Wielka Brytania, Niemcy i Stany Zjednoczone. W niektórych z nich uczestniczyli Polacy, ale jako obywatele państw zaborczych. W okresie międzywojennym akcję kongresową zainaugurowano stosunkowo póź- 
no, bo dopiero w 1925 r. w Kairze. W Kongresie tym po raz pierwszy uczestniczyła oficjalna delegacja polska. Potem odbyły się kongresy w Londynie i Cambridge (1928) oraz w Paryżu (1931) (Kish, 1992; Kosiński, 2008; Lecomte de Martonne, 1959). Ten ostatni był dla nas najważniejszy. Wtedy bowiem zapadła decyzja o przyjęciu przez Międzynarodową Unię Geograficzną zaproszenia rządu polskiego do organizacji w 1934 r. XIV Kongresu w Warszawie. W Paryżu też wiceprezydentem Unii wybrano Eugeniusza Romera (nieoficjalnie pełnił tę funkcję od 1929 r.).

Patronat honorowy nad Kongresem objęli Prezydent Rzeczypospolitej Ignacy Mościcki oraz Marszałek Polski Józef Piłsudski. XIV Kongres był pierwszym, jaki Międzynarodowa Unia Geograficzna zorganizowała w kraju słowiańskim. Polska była krajem pozbawionym swojej państwowości przez ponad 120 lat (zabory), wobec tego nie posiadała tradycji w organizacji tego rodzaju imprez. Dzięki Kongresowi język polski został formalnie równouprawniony na czas trwania spotkania z głównymi językami kongresowymi (francuskim i angielskim). Należy jednak podkreślić, że żaden z polskich uczestników nie skorzystał z tego przywileju. Sukcesem politycznym stał się udział licznej reprezentacji geografów niemieckich, którzy po raz pierwszy od zakończenia I wojny światowej pojawili się na Kongresie MUG-u (Niemcy zostały przyjęte do Unii na krótko przed spotkaniem w Warszawie). Swoją obecność zainaugurowali też Turcy.

Organizacją Kongresu zajął się Narodowy Komitet Geografii usytuowany przy Polskiej Akademii Umiejętności w Krakowie. Przewodniczącym Komitetu Organizacyjnego został Eugeniusz Romer (wiceprezydent MUG, Uniwersytet Jana Kazimierza we Lwowie) (fot. 1), jego zastępcą Antoni Sujkowski (Przewodniczący Polskiego Towarzystwa Geograficznego, Szkoła Główna Handlowa w Warszawie) (fot. 2), sekretarzem generalnym Stanisław Pawłowski (Uniwersytet Poznański) (fot. 3), skarbnikami Jerzy Loth (Szkoła Główna Handlowa) i Stanisław Lencewicz (Uniwersytet Warszawski). Członkami Komitetu byli: Jerzy Smoleński (Uniwersytet Jagielloński), Mieczysław Limanowski (Uniwersytet Stefana Batorego w Wilnie), August Zierhoffer (Uniwersytet Jana Kazimierza we Lwowie) oraz Jerzy Lewakowski (Wojskowy Instytut Geograficzny) (fot. 4). Otwarcie Kongresu, jak też obrady, miały miejsce w gmachu Politechniki Warszawskiej, natomiast zamknięcie odbyło się w auli Warszawskiego Towarzystwa Naukowego w Pałacu Staszica (Zierhoffer, 1935). Dodajmy, że swoją siedzibę miał tam Zakład Geograficzny Uniwersytetu Warszawskiego.

Otwarcie Kongresu miało charakter bardzo uroczysty. Honorowe miejsce zajął Prezydent RP Ignacy Mościcki. Przybył on w towarzystwie m.in. zastępcy premiera ministra skarbu W.M. Zawadzkiego (w ówczesnym rządzie L. Kozłowskiego nie było funkcji wicepremiera), marszałka Sejmu K. Świtalskiego, szefa Ministerstwa Spraw Zagranicznych J. Becka, Ministra Wyznań Religijnych i Oświecenia Publicznego W. Jędrzejewicza i Komisarza rządu RP na m.st. Warszawę W. Jaroszewicza. W pierwszych rzędach zasiedli szefowie placówek dyplomatycznych państw uczestniczących w Kongresie (fot. 5). 


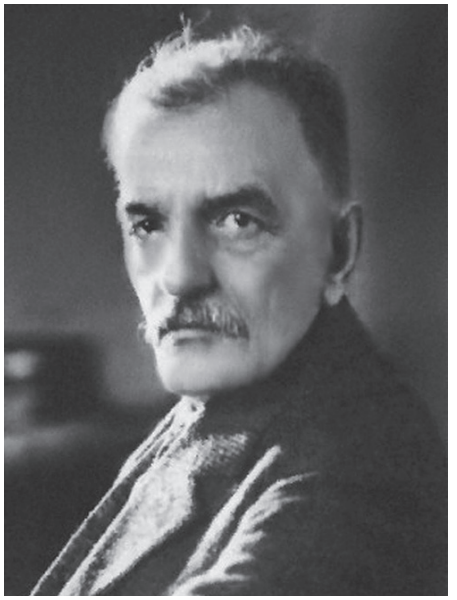

Fot. 1.

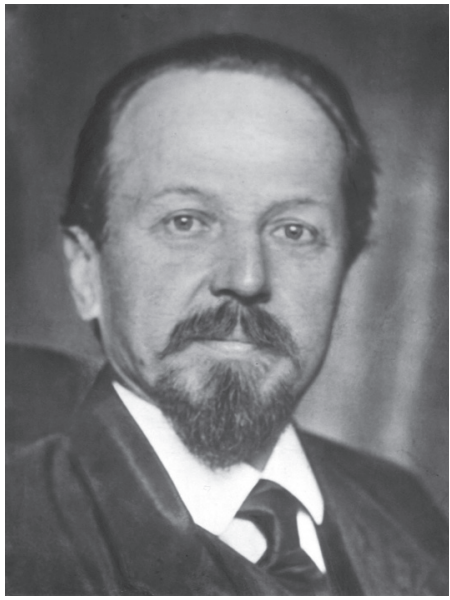

Fot. 2.

Fot. 1. Eugeniusz Romer, wiceprezydent Międzynarodowej Unii Geograficznej w latach 1929-1938 i 1945-1949, przewodniczący Komitetu Organizacyjnego, Uniwersytet Jana Kazimierza we Lwowie. Źródło: Archiwum IGiGP UJ.

Fot. 2. Antoni Sujkowski, przewodniczący Polskiego Towarzystwa Geograficznego, zastępca przewodniczącego Komitetu Organizacyjnego, Szkoła Główna Handlowa w Warszawie. Źródło: Archiwum IGiGP UJ.

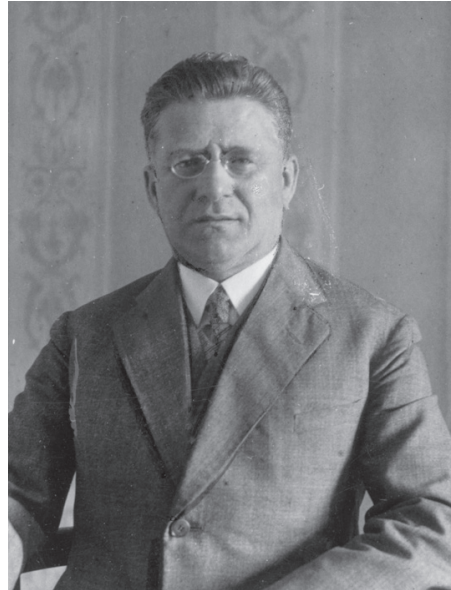

Fot. 3.

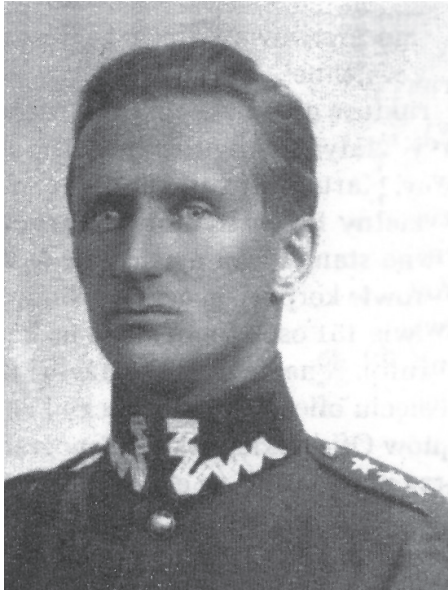

Fot. 4.

Fot. 3. Stanisław Pawłowski, wiceprezydent Międzynarodowej Unii Geograficznej w latach 1938-1939, sekretarz generalny Komitetu Organizacyjnego, Uniwersytet Poznański. Źródło: Narodowe Archiwum Cyfrowe (NAC) 1-N-439.

Fot. 4. Jerzy Lewakowski, późniejszy szef Wojskowego Instytutu Geograficznego, członek Komitetu Organizacyjnego, organizator międzynarodowej wystawy kartografii współczesnej. Źródło: Archiwum IGiGP UJ. 


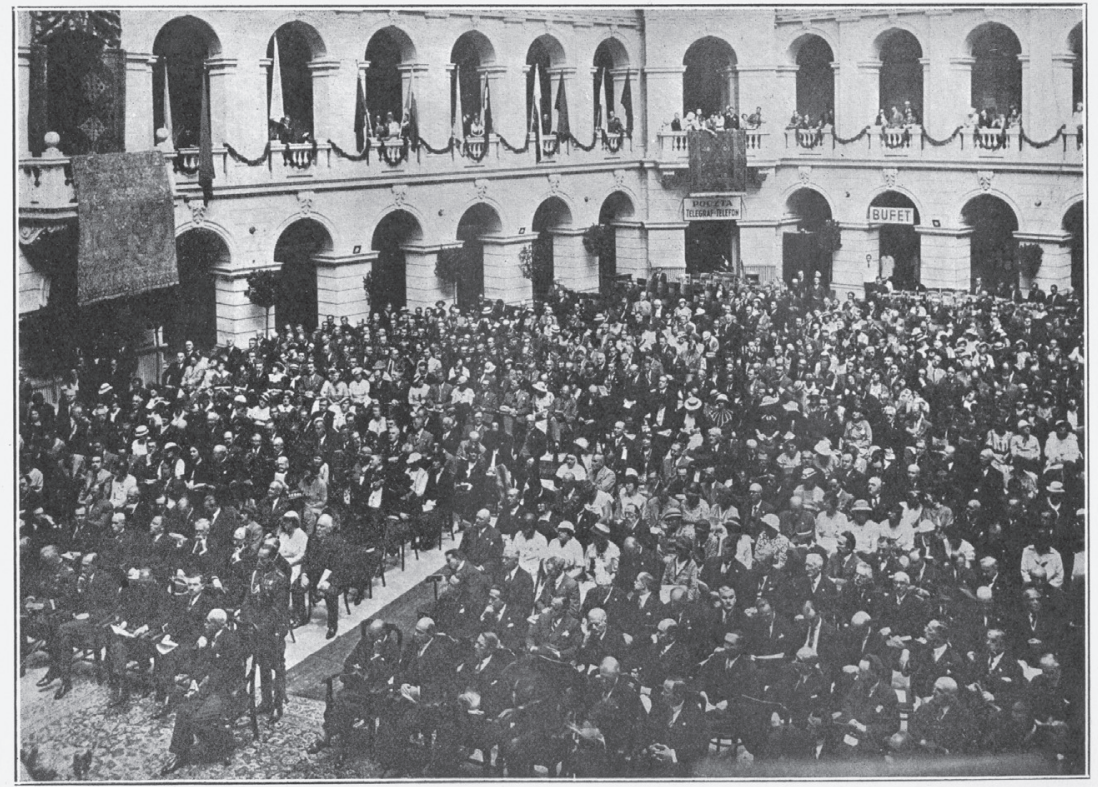

Fig. V. Séance inaugurale du Congrès International de Géographie, Varsovie 1994. Au premier plan M. le Président de la République.

Fot. 5. Otwarcie Kongresu w auli Politechniki Warszawskiej z udziałem Prezydenta RP Ignacego Mościckiego (siedzi w fotelu)

Źródło: Comptes Rendus du Congrès International de Géographie, Varsovie 1934, Warszawa 1935, s. 101.

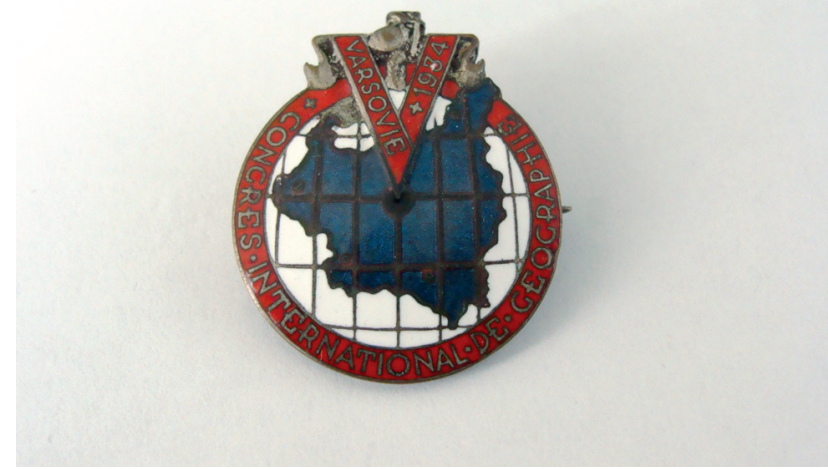

Ryc. 1. Odznaka XIV Kongresu Międzynarodowej Unii Geograficznej Źródło: Archiwum IGiGP UJ. 
Obrady otworzył Przewodniczący Międzynarodowej Unii Geograficznej Isaiah S. Bowman (Stany Zjednoczone). Po przemówieniach wstępnych (m.in. ministra W. Jędrzejewicza) głos zabrali przewodniczący oficjalnych delegacji zagranicznych, m.in. z: Belgii, Niemiec, Francji, Stanów Zjednoczonych, Wielkiej Brytanii, Włoch oraz Holandii. W imieniu delegacji niemieckiej przemawiał Ludwig Mecking, który reprezentował też rząd Rzeszy. Czytając tekst jego wystąpienia z perspektywy dnia dzisiejszego wiele zawartych tam stwierdzeń można uznać za kłamliwe, m.in. o przyjaźni ówczesnych Niemiec i wodza Hitlera w stosunku do Polski. Ze szczególną sympatią przyjęto natomiast wystąpienie szefa delegacji geografów francuskich Emmanuela de Martonne’a, który mówił m.in.: „Geografia polska istniała nawet wtedy, gdy nie było Polski”. Przywołując dorobek L. Sawickiego i E. Romera podkreślił, że „od 15 lat dorobek Polski Niepodległej w dziedzinie geograficznej jest olbrzymi. [...] Rzut oka na Polskę pozwala stwierdzić, że jest ona organizmem geograficznym szczególnie godnym uwagi” (Ilustrowany Kurier Codzienny (IKC), 1934, no. 235 (25 sierpnia), s. 13). Eugeniusza Romera nazwał „architektem gmachu geografii polskiej”.

Charles Close, szef Brytyjskiego Towarzystwa Geograficznego, odnosząc się do rangi geografii we współczesnym świecie powiedział m.in.: „Świat pojęty jako ojcowizna Człowieka - oto wielki motyw naszej nauki" (IKC, 1934, no. 235 (25 sierpnia), s. 13). Dodajmy w tym miejscu, że w Warszawie Ch. Close został wybrany kolejnym Przewodniczącym MUG.

Ostatnim mówcą podczas uroczystości otwarcia Kongresu był E. Romer. Witając przybyłych gości w imieniu polskich geografów mówił m.in.: „Pojęcie Polski nigdy nie zapomnianej, dziś odrodzonej, tworzącej się, idącej ku nowym światom, wysunąłem z umysłu na front. To pojęcie [tzn. Polska] was przede wszystkim znęciło do przyjazdu i ta świadomość powagi, z jaką Polska pragnie być przez Was poznaną" (IKC, 1934, no. 235 (25.08), s. 14).

Na zakończenie pierwszego dnia Kongresu Prezydent Mościcki gościł geografów z całego świata w Zamku Królewskim w Warszawie.

W Kongresie uczestniczyły 693 osoby z 44 krajów świata. Z Polski wzięło udział 367 osób i była to najliczniejsza grupa uczestników. Ponadto wyróżniającymi się grupami byli: Francuzi (87 osób), Niemcy (50), Brytyjczycy (44), Włosi (43), Belgowie (23), Amerykanie i Hiszpanie (po 10 osób). Kilku geografów liczyła delegacja sowiecka. Obok uczonych związanych z ośrodkami uniwersyteckimi i innymi placówkami badawczymi w Kongresie uczestniczyli również przedstawiciele różnych zagranicznych ministerstw, wojska i marynarki. Z zagranicy przyjechali m.in.: L. Aufrère, H. Baulig, A. Briquet, A. Cholley, P. Deffontaines, P. George, T. Lefebvre, E. de Martonne, M. Pardé, M. Sorre (Francja), C. Close, C.B. Fawcett, H. Winterbotham (Wielka Brytania), J. Büdel, M. Eckert, N. Krebs, L. Mecking, P. Woldstedt ${ }^{1}$ (Niemcy), R. Almagià, G. Dainelli, M. Gor-

\footnotetext{
${ }^{1}$ Profesor Paul Woldstedt, wybitny niemiecki geolog i geomorfolog, przyjaźnił się z Dyrektorem Instytutu Geograficznego UJ prof. Jerzym Smoleńskim. Obaj wiele czasu spędzili razem podczas Kon-
} 
tani, G. Nangeroni (Włochy), N. Barański, J.M. Shokalsky (Związek Sowiecki), B. Z. Milojević, P. Vujević (Jugosławia), P.L. Michotte, O. Tulippe (Belgia), C. Biermann, M. Lugeon, C. Schneider (Szwajcaria), W.E. Baerman (Holandia), P. Teleki (Węgry), A. Sőderlund, H. Stalberg (Szwecja), I.S. Bowman, E. Raisz (Stany Zjednoczone), T. Odauti (Japonia). Jeżeli chodzi o delegację polską, to czołówkę stanowili pracownicy ośrodków uniwersyteckich, ponadto uczestnikami byli również nauczyciele, krajoznawcy, studenci oraz sympatycy geografii. Podczas obrad wygłoszono około 250 referatów, przy czym najwięcej wystąpień mieli Francuzi. Prace toczyły się w sześciu sekcjach: kartograficznej, geografii fizycznej, antropogeograficznej, geografii przedhistorycznej, historycznej i historii geografii, krajobrazu geograficznego oraz nauczania geografii (tab. 1).

Tabela 1. Sekcje podczas XIV Kongresu Międzynarodowej Unii Geograficznej w Warszawie

\begin{tabular}{|c|c|c|c|}
\hline Lp. & Sekcja & Przewodniczący & Gospodarz \\
\hline 1 & kartograficzna & $\begin{array}{l}\text { I.G. Steese (Stany Zjednoczone), } \\
\text { H. Winterbotham (Wielka } \\
\text { Brytania) }\end{array}$ & $\begin{array}{l}\text { płk. T. Zieleniewski (geodeta, } \\
\text { kartograf, komendant Wojskowe- } \\
\text { go Instytutu Geograficznego) }\end{array}$ \\
\hline 2 & geografii fizycznej & $\begin{array}{l}\text { H. Baulig (Francja), } \\
\text { J.M. Shokalsky (Związek } \\
\text { Sowiecki) }\end{array}$ & $\begin{array}{l}\text { prof. S. Lencewicz (geograf, } \\
\text { Uniwersytet Warszawski) }\end{array}$ \\
\hline 3 & antropogeograficzna & C.B. Fawcett (Wielka Brytania) & $\begin{array}{l}\text { prof. A. Zierhoffer (geograf, } \\
\text { Uniwersytet Jana Kazimierza } \\
\text { we Lwowie) }\end{array}$ \\
\hline 4 & $\begin{array}{l}\text { geografii przedhisto- } \\
\text { rycznej, historycznej } \\
\text { i historii geografii }\end{array}$ & R. Almagià (Włochy) & $\begin{array}{l}\text { prof. W. Semkowicz (historyk, } \\
\text { Uniwersytet Jagielloński) }\end{array}$ \\
\hline 5 & $\begin{array}{l}\text { krajobrazu } \\
\text { geograficznego }\end{array}$ & L. Mecking (Niemcy) & $\begin{array}{l}\text { prof. J. Smoleński (geograf, } \\
\text { Uniwersytet Jagielloński) }\end{array}$ \\
\hline 6 & nauczania geografii & P.L. Michotte (Belgia) & $\begin{array}{l}\text { K. Bzowski (geograf, Zrzeszenie } \\
\text { Polskich Nauczycieli Geografii) }\end{array}$ \\
\hline
\end{tabular}

Opracowanie własne.

Kartografowie dyskutowali przede wszystkim nad sposobami prezentowania urzeźbienia terenu na mapach oraz metodami fotogrametrii lotniczej. Zaintere-

gresu w Warszawie. Na wieść o zamordowaniu J. Smoleńskiego w obozie koncentracyjnym Sachsenhausen P. Woldstedt zaangażował się w pomoc wdowie. Przybyła ona do Berlina w dniu 6 stycznia 1940 r. wraz z synem Stanisławem, księdzem i późniejszym biskupem, natychmiast po otrzymaniu zawiadomienia z obozu o śmierci Profesora. Na wyjazd z Krakowa otrzymała specjalną przepustkę z gestapo. W Berlinie Woldstedt zaopiekował się żoną i synem swego przyjaciela. Dzięki swoim kontaktom ułatwił im dojazd do obozu Sachsenhausen, gdzie mieli możliwość zobaczenia zwłok męża i ojca oraz pożegnania się z nim. Było to wydarzenie wyjątkowe. Z pewnością był to również jeden z nielicznych przypadków, gdy Niemiec odważył się interweniować w gestapo w sprawie Polaka. Potem ciało Smoleńskiego zostało skremowane, a berliński uczony dopilnował, aby w urnie przesłanej do wdowy rzeczywiście znalazły się prochy krakowskiego Profesora. Po wojnie prof. Woldstedt utrzymywał kontakt z uczniem prof. Smoleńskiego - Mieczysławem Klimaszewskim. 
sowanie wzbudzała też metodologia sporządzania kartogramów i map syntetycznych. W sekcji wygłoszono 40 referatów.

W trakcie obrad związanych z geografią fizyczną zanotowano 79 wystąpień. Wiązały się one głównie z badaniami nad czwartorzędem. Ponadto dyskutowano nad dawnymi powierzchniami erozyjnymi oraz problematyką teras rzecznych i morskich.

W sekcji antropogeograficznej (82 referaty) koncentrowano się na problematyce lokalizacji działalności przemysłowej, geografii miast (zwłaszcza badania ich fizjonomii), przeludnienia oraz osadnictwa wiejskiego. W zakresie tej ostatniej problematyki spore sukcesy odnieśli geografowie polscy. Szczególne zainteresowanie wzbudzały mapy osadnicze Polski (1:500 000) opracowane przez S. Pawłowskiego i J. Czekalskiego. Ukazywały one stopień skupienia lub rozproszenia osiedli wiejskich w skali całego kraju. Studia szczegółowe związane z tym tematem prezentowali J. Czyżewski (Polska południowo-wschodnia), S. Leszczycki i S. Zajchowska (Karpaty Zachodnie), M. Kiełczewska (Pomorze), B. Zaborski (Wileńszczyzna) i T. Senik (Roztocze).

W porównaniu z poprzednimi kongresami nowością było specjalne posiedzenie poświęcone problemom geografii kraju organizującego imprezę. Podczas „Dnia Polskiego” (24 sierpnia) wykłady prezentowali wybitni naukowcy - zarówno geografowie, jak też geolodzy, historycy i etnolodzy. Największe wrażenie wywołały referaty E. Romera Podstawowe zagadnienia geografii ekonomicznej w Polsce oraz M. Limanowskiego o znaczeniu geograficznym pięciu największych miast ówczesnej Polski - Poznania, Krakowa, Lwowa, Wilna i Warszawy (Lencewicz, 1934/1935). Ponadto zorganizowano cykl ogólnodostępnych wykładów, które wygłaszali najwybitniejsi geografowie z różnych krajów.

W trakcie przerw w obradach uczestnicy mieli okazję odwiedzić niektóre stołeczne szkoły powszechne, średnie oraz szkołę handlową i Państwowy Zakład Higieny. Szczególnie wysoko oceniono Pracownię Geograficzną w Ministerstwie Wyznań Religijnych i Oświecenia Publicznego prowadzoną przez G. Wuttkego, M. Janiszewskiego i J. Peretiatkowicz. Goście z zagranicy z uznaniem wyrażali się o urządzeniach Pracowni oraz sposobach nauczania geografii w Polsce. Uczestnicy Kongresu postanowili rozpowszechnić w swoich krajach informacje o Pracowni (Polaczkówna, 1934).

Wielką atrakcję stanowiły spotkania towarzyskie. Obok wymienionej już recepcji w Zamku Królewskim odbyły się one w Prezydium Rady Ministrów, w Ratuszu wydane przez Prezydenta Warszawy S. Starzyńskiego z małżonką oraz w Resursie Obywatelskiej, zorganizowane na zakończenie Kongresu przez Komitet Organizacyjny i połączone z wielkim balem w Hotelu „Bristol”. W konserwatorium warszawskim zorganizowano dla uczestników koncert z udziałem wybitnych muzyków.

Z okazji Kongresu Polskie Towarzystwo Geograficzne wybiło specjalny medal z podobizną W. Nałkowskiego i pamiątkowym napisem w języku łacińskim. 
Medale srebrne otrzymali: I.S. Bowman, E. de Martonne, E. Romer oraz S. Pawłowski, natomiast wszyscy uczestnicy zagraniczni dostali medale brązowe.

Podsumowania merytorycznego Kongresu dokonał E. Romer podczas uroczystego zakończenia. Prezentowane podczas Kongresu materiały opublikowano w latach 1935-1938 w 4 tomach pod zbiorczym tytułem Comptes Rendus du Congrès International de Géographie (fot. 6).

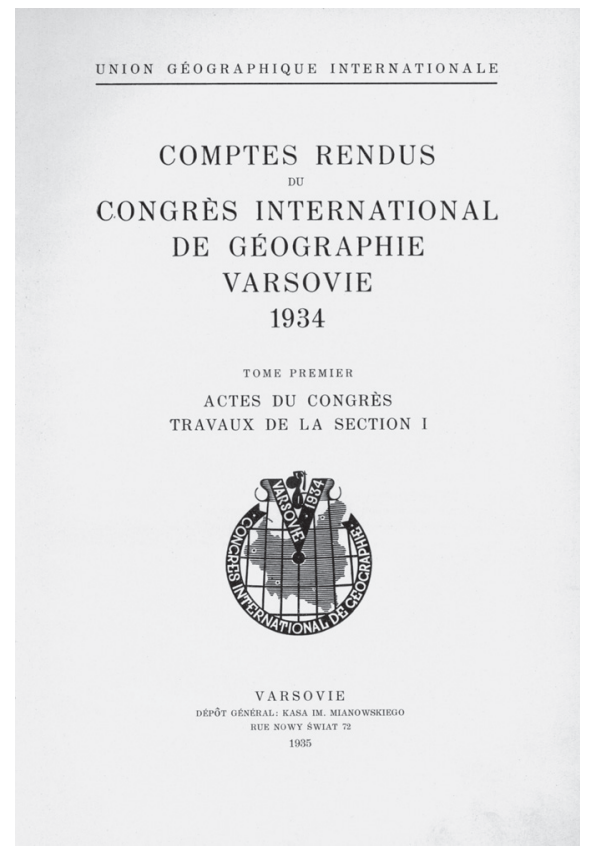

Fot. 6. Strona tytułowa 1 tomu Comptes Rendus du Congrès International de Géographie, Varsovie 1934.

Podczas dwóch sesji Międzynarodowej Unii Geograficznej jednym z wiceprezydentów wybrano E. Romera. Ponadto do różnych komisji MUG powołano S. Pawłowskiego. J. Czekalskiego, S. Lencewicza, J. Czyżewskiego i H. Arctowskiego. Delegaci ustosunkowali się też do wniosków zgłaszanych podczas obrad sekcji. Wymieńmy dwie zatwierdzone propozycje: (1) o utworzeniu „Towarzystwa im. Joachima Lelewela”, które miało prowadzić badania z zakresu historii geografii; (2) o zwróceniu się do rządów poszczególnych państw z apelem, aby ze względu na wybitne walory wychowawcze geografia weszła do programów szkół wszelkich typów i poziomów (IKC, 1934. no. 243 (2.09), s. 5).

Kongresowi towarzyszyły ekspozycje: międzynarodowa wystawa kartografii współczesnej w gmachu Politechniki Warszawskiej - organizator J. Lewakowski 
(Wojskowy Instytut Geograficzny); wystawa zbiorów kartograficznych Biblioteki Narodowej - organizatorzy K. Buczek, B. Olszewicz, J. Stebnowski; wystawa pt. Jak powstaje mapa - organizator T. Krzanowski (Wojskowy Instytut Geograficzny); wystawa polskiej kartografii współczesnej - organizator S. Pietkiewicz (Uniwersytet Warszawski); wystawa mapy międzynarodowej. Ponadto w budynku Towarzystwa Zachęty Sztuk Pięknych zorganizowano wystawę malarską pt. Polska $i$ jej lud. Wszystkie wystawy miały drukowane katalogi, wydane w języku polskim i francuskim. Katalog ekspozycji Biblioteki Narodowej opracowali K. Buczek oraz B. Olszewicz.

Międzynarodową Wystawę Kartograficzną zorganizowano z inicjatywy polskiej. W uroczystości otwarcia uczestniczył Prezydent RP I. Mościcki (fot. 7). Była to pierwsza tego typu ekspozycja na świecie. Do udziału zaproszono oficjalne państwowe (wojskowe) instytucje kartograficzne, topograficzne i geograficzne. Swój dorobek reprezentowało 35 państw, łącznie wystawa liczyła ponad 2500 obiektów. Szczególnymi walorami wyróżniała się kartografia polska. Organizatorzy nakreślili trzy główne cele ekspozycji: (1) ukazanie typów map topograficznych w poszczególnych państwach; (2) przedstawienie głównych typów krajobrazu fizycznego i kulturowego; (3) zademonstrowanie rozwoju podstawowych map topograficznych. Po zamknięciu wystawy prezentowane materiały przekazano do zbiorów Biblioteki Narodowej oraz Wojskowego Instytutu Geograficznego (Lewakowski, 1934; Pietkiewicz, 1934/1935).

Wystawę zbiorów kartograficznych Biblioteki Narodowej podzielono na 4 główne części: (1) mapy ogólne Polski przedrozbiorowej (do 1795 r.); (2) mapy ogólne Polski historycznej (1795-1918); (3) mapy szczegółowe Polski przedrozbiorowej; (4) mapy szczegółowe Polski historycznej do 1918 r. Wśród wystawianych egzemplarzy wiele map miało charakter rękopiśmienniczy. Ponadto zorganizowano specjalne stoisko z pracami Joachima Lelewela (Stebnowski, 1934/1935).

Wystawa polskiej kartografii współczesnej przedstawiała dorobek z lat 19181934. Zgromadzono 400 eksponatów (arkuszy) map nadesłanych przez Państwowy Instytut Geologiczny, Karpacką Stację Geologiczno-Naftową, Polską Akademię Umiejętności, placówki uniwersyteckie, Państwowy Instytut Meteorologiczny, Służbę Hydrograficzną, Główny Urząd Statystyczny, Instytut Kartograficzny im. E. Romera, wydawnictwo „Pomoc Szkolna” czy Związek Nauczycielstwa Polskiego; swoje opracowania kartograficzne prezentował także B. Zaborski. Były to głównie mapy geologiczne, geomorfologiczne, gleboznawcze, meteorologiczne, hydrologiczne, morskie, gospodarcze, demograficzne, komunikacyjne, turystyczne. W dziale map szkolnych dominowała oficyna wydawnicza „Książnica-Atlas”, prezentująca około sto map (Pietkiewicz, 1934/1935).

Zorganizowano 12 wycieczek o charakterze regionalnym i problemowym (tab. 2, ryc. 2). Wzięły w nich udział 244 osoby. Wycieczki kilkudniowe miały miejsce przed i po Kongresie. Przed Kongresem odbyły się 3 wycieczki, w których łącznie wzięły udział 62 osoby (fot. 8). Podczas dni kongresowych uczestnicy 
mogli skorzystać z 3 wycieczek jednodniowych. Uczestniczyło w nich 106 osób. Natomiast po Kongresie zorganizowano 4 wycieczki, w których wzięło udział 76 osób (fot. 9). Wszystkie wycieczki miały przygotowane i starannie wydane przewodniki, które do dnia dzisiejszego są cenione przez geografów (fot. 10).

Tabela 2. Wycieczki zorganizowane dla uczestników Kongresu

\begin{tabular}{|c|c|c|c|c|}
\hline & Region & $\begin{array}{l}\text { Czas trwania } \\
\text { (dni) }\end{array}$ & Kierownik & $\begin{array}{c}\text { Liczba } \\
\text { uczestników }\end{array}$ \\
\hline \multirow[t]{3}{*}{$\begin{array}{l}\text { Przed roz- } \\
\text { poczęciem } \\
\text { Kongresu }\end{array}$} & Polesie i Białowieża & 7 & $\begin{array}{l}\text { S. Lencewicz, } \\
\text { S. Pawłowski }\end{array}$ & 15 \\
\hline & Podole i Karpaty Wschodnie & 9 & $\begin{array}{l}\text { J. Czyżewski, } \\
\text { A. Zierhoffer }\end{array}$ & 14 \\
\hline & Kraków, dolina Dunajca, Tatry & 8 & J. Smoleński & 33 \\
\hline \multirow{4}{*}{$\begin{array}{l}\text { W trakcie } \\
\text { Kongresu }\end{array}$} & Dolina Wisły w okolicach Płocka & 1 & S. Lencewicz & 39 \\
\hline & Dolina Wisły w okolicach Warszawy & 1 & J. Lewiński & 17 \\
\hline & Puławy-Kazimierz & 1 & B. Zaborski & 25 \\
\hline & Zwiedzanie Warszawy & 1 & $\begin{array}{l}\text { R. Danysz- } \\
\text {-Fleszarowa }\end{array}$ & 25 \\
\hline \multirow{5}{*}{$\begin{array}{l}\text { Po zakoń- } \\
\text { czeniu Kon- } \\
\text { gresu }\end{array}$} & $\begin{array}{l}\text { Północno-wschodnia Polska, } \\
\text { dorzecze Niemna i Dźwiny }\end{array}$ & 5 & $\begin{array}{l}\text { M. Limanow- } \\
\text { ski }\end{array}$ & 13 \\
\hline & Pomorze i wybrzeże Bałtyku & 7 & S. Pawłowski & 26 \\
\hline & $\begin{array}{l}\text { Masyw hercyński Łysogór i jego } \\
\text { pokrywy mezozoiczne }\end{array}$ & 5 & S. Lencewicz & 17 \\
\hline & Śląsk Polski & 4 & W. Ormicki & 10 \\
\hline & $\begin{array}{l}\text { Dolina Wisły i miasta przemysłowe } \\
\text { oraz uzdrowiska }\end{array}$ & 6 & J. Loth & 10 \\
\hline
\end{tabular}

Opracowanie własne na podstawie: Lencewicz (1934/1935).

Z okazji Kongresu opublikowano pod red. A. Patkowskiego dwutomową pracę Ruch regionalistyczny $w$ Europie (Warszawa, 1934), zawierająca m.in. opracowania S. Pawłowskiego: Regionalizm geograficzny i jego rozwój w Polsce oraz W. Ormickiego: Regionalizm gospodarczy w Polsce. Ponadto w trakcie obrad odbyła się specjalna sesja poświęcona jubileuszowi 40-lecia pracy naukowej Eugeniusza Romera. Z tej okazji Jubilatowi wręczono dedykowane mu wydawnictwo pt. Zbiór prac poświęcony przez Towarzystwo Geograficzne we Lwowie Eugeniuszowi Romerowi w 40-lecie jego twórczości naukowej (Lwów, 1934). Redaktorem był H. Arctowski, a sama publikacja liczyła blisko 700 stron. Swoje artykuły nadesłali geografowie polscy i zagraniczni, z których większość uczestniczyła w kongresie warszawskim. 


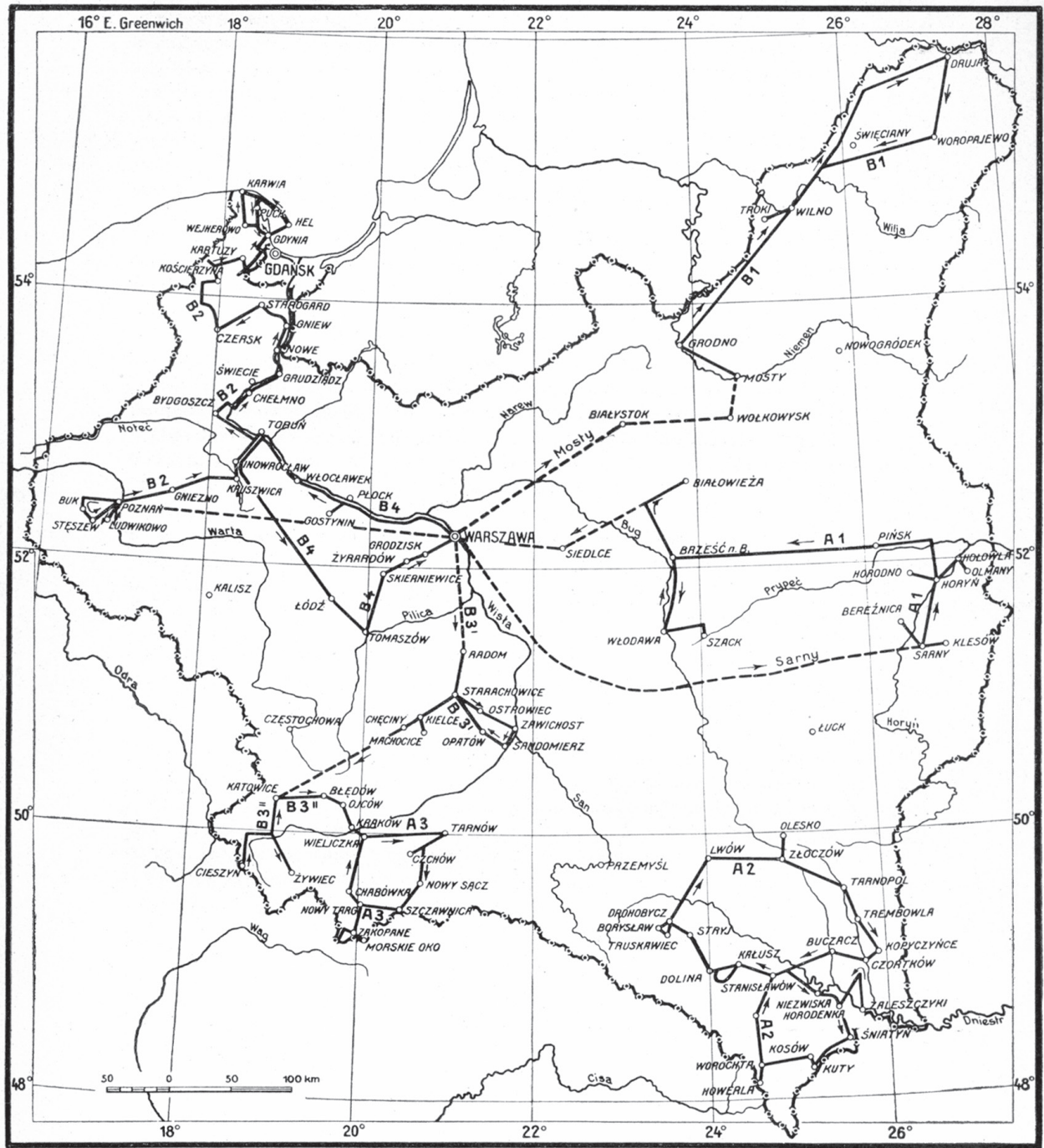

Fig. IV. Itinéraires d'excursions du Congrès International de Géographie à Varsovie.

Ryc. 2. Trasy wycieczek związanych z XIV Kongresem Międzynarodowej Unii Geograficznej. Źródło: Comptes Rendus du Congrès International de Géographie, Varsovie 1934, Warszawa 1935, s. 81. 


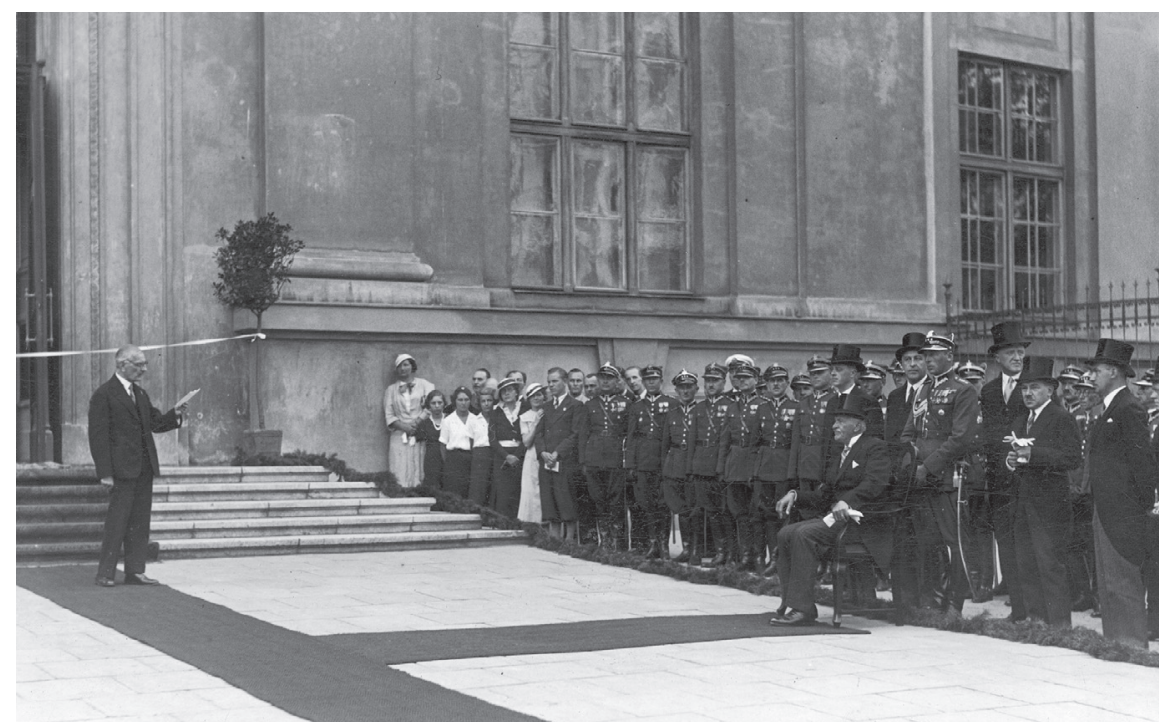

Fot. 7. Otwarcie Międzynarodowej Wystawy Kartografii Współczesnej, Politechnika Warszawska. Przemawia Eugeniusz Romer. W uroczystości uczestniczył Prezydent RP Ignacy Mościcki (siedzi w fotelu). Drugi od prawej zastępca premiera minister skarbu Władysław Marian Zawadzki (trzyma białe rękawiczki). Źródło: NAC 1-M-521-4.

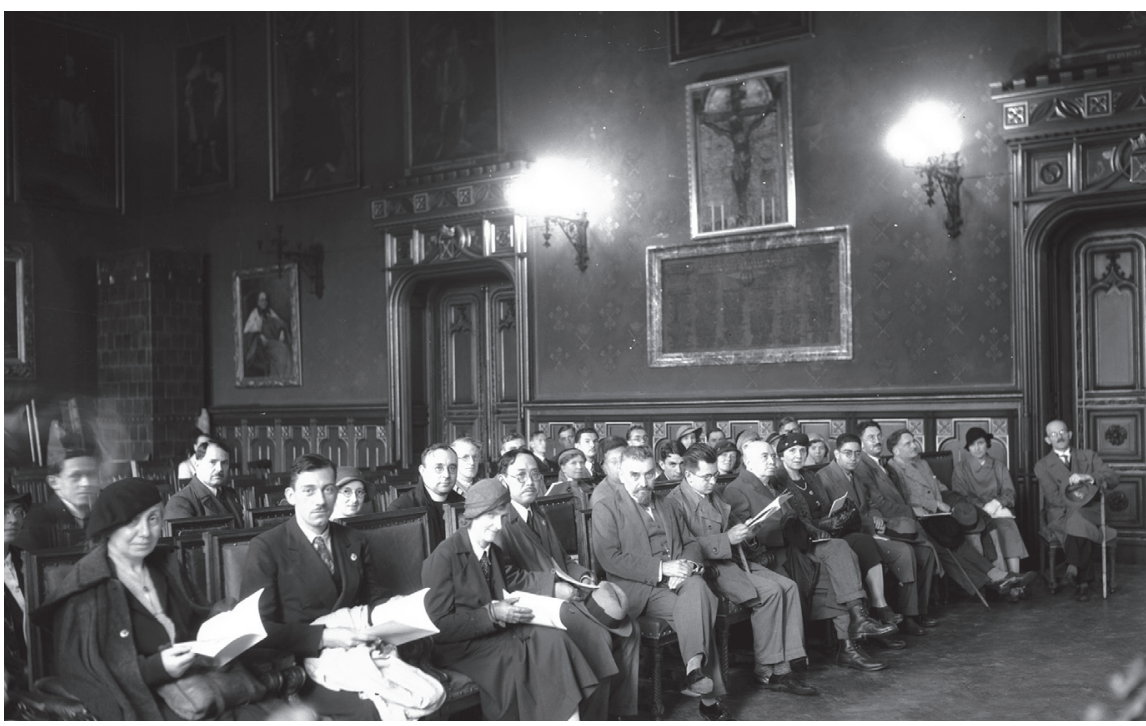

Fot. 8. Uczestnicy wycieczki do Krakowa w auli Uniwersytetu Jagiellońskiego. Pierwszy z prawej Jerzy Smoleński. Źródło: NAC 1-M-522-1. 


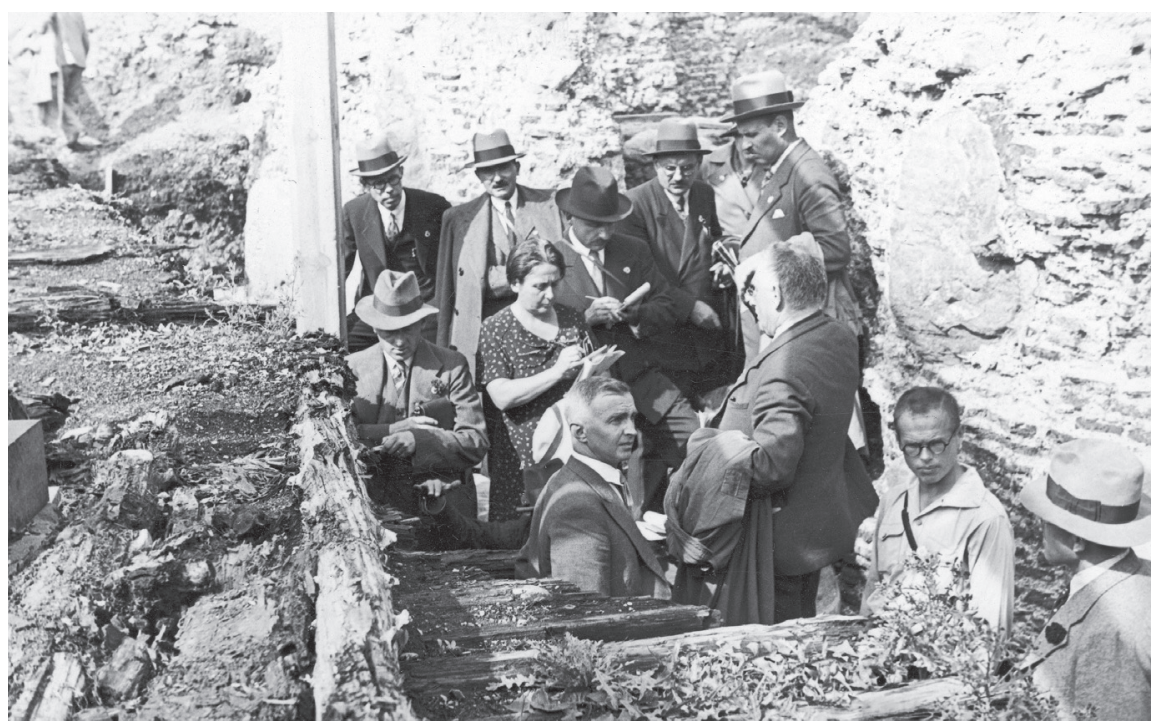

Fot. 9. Uczestnicy wycieczki po południowo-wschodniej Polsce podczas zwiedzania wykopalisk na Starym Zamku w Grodnie. Trzeci z prawej (z płaszczem na ręku) Mieczysław Limanowski. Źródło: NAC 1-M-523-1.

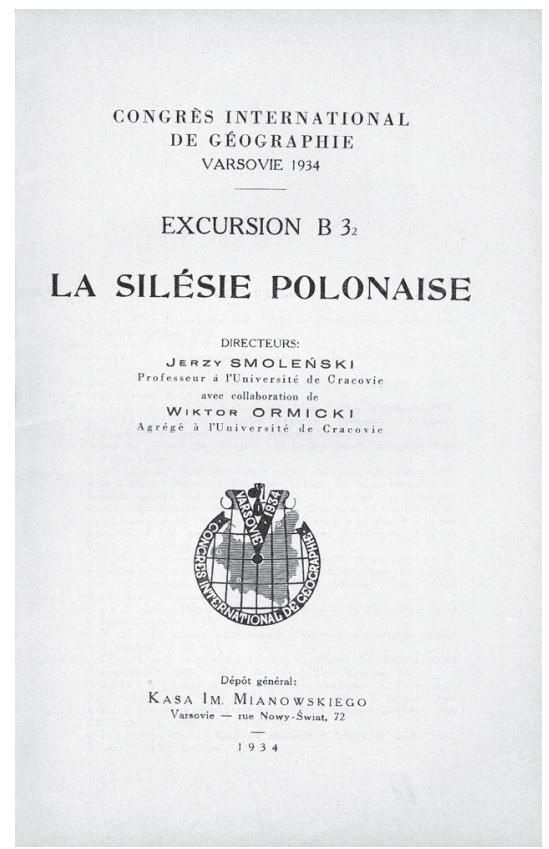

Fot. 10. Strona tytułowa przewodnika wycieczki na Śląsk autorstwa Jerzego Smoleńskiego i Wiktora Ormickiego 
XIV Kongres Międzynarodowej Unii Geograficznej został bardzo wysoko oceniony zarówno przez władze organizacji, jak też przez uczestników. Znalazło to wyraz m.in. w licznych relacjach bardziej lub mniej naukowych, które ukazywały się w różnych periodykach zagranicznych. Zdecydowanie najwięcej omówień opublikowano w Niemczech, przy czym nie wszystkie takie prace były obiektywne. Niektóre miały charakter wyraźnie polityczny, np. te, w których przy okazji omówienia wycieczek na tereny byłego zaboru pruskiego kwestionowano przynależność tych obszarów do Polski. Najwięcej tego typu uwag odnosiło się do wycieczki na Śląsk i związanego z nią przewodnika, opracowanego przez J. Smoleńskiego i W. Ormickiego. Sprawozdania z Kongresu ukazywały się w wydawnictwach francuskich, włoskich, brytyjskich, szwedzkich, litewskich, amerykańskich, bułgarskich, czechosłowackich.

Przede wszystkim wysoko oceniano poziom merytoryczny Kongresu i jego wielki wkład w rozwój nauki światowej w ogóle, a szczególnie geografii. Podkreślano dobrą organizację i wysoki poziom wystąpień, który spowodował, że w poszczególnych sekcjach dyskusje trwały niekiedy po kilka godzin. Wysoką ocenę wystawiono zorganizowanym wycieczkom. Zwracano uwagę na trafność doboru poszczególnych tras i świetne przygotowanie merytoryczne kierowników. Największe wrażenie zrobiły na uczestnikach wycieczki na Polesie, do Krakowa i w Tatry oraz nad Bałtyk.

Wiele miejsca w relacjach pokongresowych zajmowała ocena wystaw kartograficznych. Podkreślono doniosłość polskiej inicjatywy zorganizowania w Warszawie wielkiej wystawy kartografii światowej. Ekspozycja taka odbywała się po raz pierwszy, a autorzy relacji sugerowali kolejnym organizatorom kongresów kontynuowanie tej akcji (Czekalski, 1934/1935; Kish, 1979).

Kongres stanowił doskonałą okazję do promocji Polski. Każdy uczestnik otrzymał wiele wydawnictw obcojęzycznych o Polsce, jak również niemal wszystkie polskie prace geograficzne z okresu pięciu lat przed Kongresem. Polscy geografowie udowodnili, że w wielu dziedzinach mają osiągnięcia równe lub przewyższające dorobek kolegów zagranicznych. Najbardziej zaznaczało się to w przypadku antropogeografii (zwłaszcza problematyki związanej z osadnictwem wiejskim) i geomorfologii. Wystawa kartografii światowej udowodniła, że nasze osiągnięcia w tej dziedzinie, a zwłaszcza mapy wydawane przez Wojskowy Instytut Geograficzny mają poziom światowy, zaś technologia ich sporządzania nie odbiega od stosowanej za granicą. W trakcie Kongresu i wycieczek goście zagraniczni mieli możliwość odwiedzenia niektórych ośrodków geograficznych (obok Warszawy również Kraków, Poznań, Wilno).

Z okazji zamknięcia Kongresu S. Pawłowski opublikował w Gazecie Polskiej okolicznościowy artykuł, stanowiący swego rodzaju komentarz do tego, o czym mówiono podczas warszawskiego spotkania geografów. Tekst zaczyna się od 
słów: „Geografia posiada ogromne międzynarodowe a równocześnie państwowe znaczenie. Ziemia jest jedna i jedna tylko może być syntetyczna nauka o ziemi. Nauką tą jest od z górą lat dwóch tysięcy geografia”. W innym miejscu odnajdujemy myśl: „Geografia jest nauką porozumienia i zgody między narodami. Nieraz już wśród geografów rodzili się apostołowie haseł uniwersalizmu ziemskiego i braterstwa ludów. Geografia w wielkich swoich działach, jakimi są kartografia, geografia fizyczna i geografia człowieka spełniała i spełnia ważną rolę jednoczenia ludzkości. Gmach geograficznej wiedzy, zbudowanej wspólnym wysiłkiem narodów świata, służy wszystkim.[...] Geografia ma wielkie zasługi w służbie ludzkości i dla ludzkości. Równocześnie jednak geografia służy narodom i państwom. [...] Geografia daje obraz realnych możliwości w rozwoju państw i tych warunków, w których rozwój ten odbywać się może.

Znawstwo tego kawałka powierzchni ziemi, na którym losy postawiły społeczeństwa, jest nieodzownym krokiem mądrego adaptowania się ludzkości do warunków przyrodzonych. Znajomość zaś geografii innych krajów na ziemi jest jedyną poważną podstawą normowania stosunków międzyludzkich i międzypaństwowych. Stąd geografia służy państwom i narodom jak rzadko która z nauk" (Pawłowski, 1934).

Słowa te stanowią najlepszą pointę w rozważaniach o randze geografii i kongresów geograficznych w procesie stabilizacji stosunków międzyludzkich i międzynarodowych. Mimo że autor wypowiadał je przed 80 laty, do dziś nie straciły na aktualności.

\section{Piśmiennictwo / References}

Czekalski J., 1934/1935, Les échos du Congrès International de Géographie de Varsovie, Przegląd Geograficzny, 14, 3-4, s. 188-194.

Ilustrowany Kurier Codzienny (IKC), 1934, 235 (25 VIII), s. 13-14.

Ilustrowany Kurier Codzienny (IKC), 1934, 243 (2 IX), s. 5.

Kish G., 1979, Bibliography of International Geographical Congresses 1871-1976, G.K. Hall, Boston.

Kish G., 1992, International Geographical Union: A brief history, GeoJournal, 26, 2, s. 224-228.

Kosiński L.A., 2008, Międzynarodowa Unia Geograficzna, [w:] A. Jackowski, S. Liszewski, A. Richling (red.), Historia geografii polskiej, Wydawnictwo Naukowe PWN, Warszawa, s. 477-488.

Lecomte De Martonne H., 1959, Historie de l'Union Géographique Internationale et de Congrès internationaux de géographie, The IGU - Newsletter, 10, Zürich, IGU, s. 3-20.

Lencewicz S., 1934/1935, Międzynarodowy Kongres Geograficzny w Warszawie, Przegląd Geograficzny, 14, 3-4, s. 167-182.

Lewakowski J., 1934, Mapa - obraz ziemi i życia, Tygodnik Ilustrowany, 37, s. 729-730.

Pawłowski S., 1934, Na zamknięcie Międzynarodowego Kongresu Geograficznego w Polsce, Gazeta Polska, 6, 241. 
Pietkiewicz S., 1934/1935, Międzynarodowa wystawa kartografii wspótczesnej, Przegląd Geograficzny, 14, 3-4, s. 182-183.

Polaczkówna M., 1935, Sprawozdanie z posiedzeń sekcji VI (Dydaktyki i metodyki nauczania) Międzynarodowego Kongresu Geograficznego w Warszawie 23-31/VIII 1934, Czasopismo Geograficzne, 13, 1, s. 11-14.

Stebnowski J., 1934/1935, Wystawa zbiorów kartograficznych Biblioteki Narodowej, Przegląd Geograficzny, 14, 3-4, s. 184-187.

Zierhoffer A., 1935, Międzynarodowy Kongres Geograficzny w Warszawie, Czasopismo Geograficzne, 13, 1, s. 1-10.

[Wpłynęło: styczeń 2014 r.] 